\title{
A periclase-dolomite-calcite carbonatite from the Oka complex, Quebec, and its calculated volatile composition*
}

\author{
Allan H. Treiman ${ }^{1}$ and Eric J. Essene \\ Department of Geological Sciences, The University of Michigan, Ann Arbor MI 48109, USA
}

\begin{abstract}
The eutectic mineral assemblage calcite-dolomitepericlase-apatite-forsterite-magnesioferrite-pyrrhotite-alabandite in a carbonatite dike within the Oka complex, Quebec, buffers the fugacities (and partial pressures) of all gas species in C-O-H-S-F, assuming vapor saturation. At the inferred eutectic $\left(640^{\circ} \mathrm{C}, 1 \mathrm{kbar}\right)$, the most important gas species and their partial pressures (bars) were: $\mathrm{H}_{2} \mathrm{O}, 882$; $\mathrm{CO}_{2}, 110 ; \mathrm{H}_{2}, 4.6 ; \mathrm{H}_{2} \mathrm{~S}, 2.7 ; \mathrm{CO}, 0.5$; and $\mathrm{CH}_{4}, 0.1$. Oxygen fugacity was near the QFM buffer, $\log f\left(\mathrm{O}_{2}\right)=-18.6$, and sulfur fugacity was near the QFM-pyrrhotite buffer, $\log f\left(\mathrm{~S}_{2}\right)=-5.9$. Fluorine fugacity was $\operatorname{low}, \log f\left(\mathrm{~F}_{2}\right)=-$ 43.9 , consistent with the absence of fluoride minerals other than apatite. Presence of a water-rich gas phase is consistent with experiments on synthetic carbonatite systems (e.g. Fanelli et al. 1981), although compositions of the gas phase in published experiments cannot be determined exactly.
\end{abstract}

\section{Introduction}

Wyllie and Tuttle (1960) first demonstrated the importance of water in carbonatite petrogenesis by showing that excess $\mathrm{H}_{2} \mathrm{O}$ lowers the melting temperature of calcite to geologically reasonable values $\left(675^{\circ} \mathrm{C}\right.$ at $\left.1 \mathrm{kbar}\right)$. Subsequent experimental studies have included excess aqueous fluid (e.g., Wyllie and Haas 1965; Boettcher and Wyllie 1969; Fanelli et al. 1981), and it has generally been assumed that natural carbonatite magmas also coexist with an aqueous fluid. Studies of fluid and melt inclusions in carbonatites (e.g., Rankin 1975, 1977; Nesbitt and Kelly 1977; Apsden 1981) confirm the presence of a water-rich fluid in the late stages of carbonatite crystallization, but the composition of the magmatic vapor phase has not been determined.

An unusual carbonatite dike on Husereau Hill in the Oka complex (Gold 1967, 1972) provides a unique opportunity to calculate the composition of the volatiles in equilibrium with the carbonatite, because it contains an extremely restrictive mineral assemblage which fixes the fugacties of all gas species in the system C-O-H-S-F. The equilibrium mineral assemblage, calcite-dolomite-periclase-olivine-apatite-magnesioferrite-pyrrhotite-alabandite, is apparently

\footnotetext{
* Contribution no. 390 from the Mineralogical Laboratory, The University of Michigan

1 Present address: Lunar and Planetary Laboratory, The University of Arizona, Tucson, AZ 85721
}

Offprint requests to: A.H. Treiman unique among carbonatites, and is similar to the eutectic assemblage calcite-dolomite-periclase-melt-vapor found experimentally in the system $\mathrm{CaO}-\mathrm{MgO}-\mathrm{CO}_{2}-\mathrm{H}_{2} \mathrm{O}$ (Fanelli et al. 1981). Thus, the rock allows a comparison between a natural magma and its synthetic analog.

\section{Geology}

The calcite-dolomite-periclase rock occurs as a probable dike on Husereau Hill within the Oka alkaline complex, a Cretaceous pluton which also includes a concentrically layered ijolite-carbonatite intrusion and a monticellite-bearing carbonatite (Gold 1963, 1966, 1967, 1973; Gold et al. 1967; Gold and Vallée 1969; Treiman 1982). The Husereau carbonatite dike appears to be among the youngest units of the complex, intruding the ijolite-carbonatite suite. The sample studied here, designated $80 \mathrm{Hl}$, is from the southeastern flank of Husereau Hill (Gold 1972; Canadian military grid reference 18 TWF736415). No contacts between the rock and its host are seen, but the difference in composition between the periclase-carbonatite and its host suggest an intrusive relationship.

In hand sample, the Husereau dike rock is fine-grained $(>1 \mathrm{~mm}$ grain size) and holocrystalline, and is traversed by anastomosing gray zones of alteration. Calcite, dolomite, periclase, apatite, and opaque oxides are the most abundant minerals (Fig. 1). Along the altered zones, primary periclase is completely replaced by brucite, which appears as dark speckles in the rock. Weathered surfaces are rusty, and the rock is cut by late fractures filled with calcite and accessory barite. Modal mineralogy is given in Table 1. The Husereau dike contains two types of xenoliths, which constitute only a few percent of the rock. Opaque-oxide xenoliths, up to $4 \mathrm{~cm}$. diameter, are rare. More common are xenoliths rich in olivine and spinel, which are up to $1.5 \mathrm{~cm}$ in diameter. The latter xenoliths often show distinct reaction relations with the surrounding carbonatite. A full petrographic description is presented in Appendix 1.

\section{Composition and mineralogy}

Although the Husereau dike is an intrusive body, its mineralogy and composition are radically different from those of other units of the Oka complex (Gold 1963, 1972; Gold et al. 1967; Treiman 1982). Because Grenville marble crops out near Husereau Hill (Gold 1972), it might be asked whether the Husereau dike is merely a remobilized marble. 


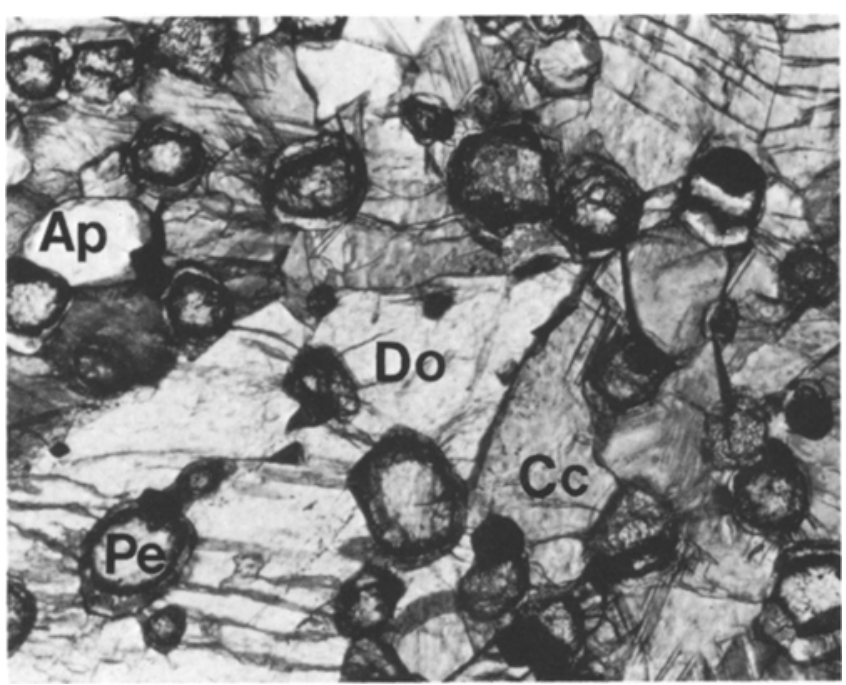

Fig. 1. Thin-section photomicrograph of the Husereau carbonatite dike, sample $80 \mathrm{Hl}$, Plane light, field is $3 \mathrm{~mm}$ across. Euhedral dolomite rhomb (light, projecting from lower left corner) in matrix of smaller calcite crystals (medium gray, stained with Alizarin red). Periclase (high relief) is surrounded by thin rims of secondary brucite, and apatite is present as anhedra (white).

Table 1. Composition of the Husereau dike rock, sample $80 \mathrm{H} 1$. Chemical analysis is average of two replicate samples. Analyses for major and minor elements (except $\mathrm{Ba}$ ) and $\mathrm{Nb}$ are by $\mathrm{X}$-ray fluorescence; all other elements determined by neutron activation analysis. All $\mathrm{Fe}$ reported as $\mathrm{Fe}_{2} \mathrm{O}_{3}$. Modal analysis is by point count ( 1,089 points) on thin sections.

\begin{tabular}{lclrlr}
\hline & wt. \% & & p.p.m. & Mode & $\%$ \\
\hline $\mathrm{SiO}_{2}$ & 0.16 & $\mathrm{La}$ & 300.0 & Calcite & 52.3 \\
$\mathrm{TiO}_{2}$ & 0.03 & $\mathrm{Ce}$ & 1040.0 & Dolomite & 15.1 \\
$\mathrm{Al}_{2} \mathrm{O}_{3}$ & 0.02 & $\mathrm{Nd}$ & 385.0 & Opaques & 7.6 \\
$\mathrm{Fe}_{2} \mathrm{O}_{3}$ & 7.58 & $\mathrm{Sm}$ & 42.3 & Periclase & 3.8 \\
$\mathrm{MnO}$ & 0.92 & $\mathrm{Eu}$ & 11.7 & Brucite & 17.5 \\
$\mathrm{MgO}$ & 19.0 & $\mathrm{~Tb}$ & 3.3 & Apatite & 3.5 \\
$\mathrm{CaO}$ & 32.1 & $\mathrm{Yb}$ & 3.1 & Olivine & 0.6 \\
$\mathrm{SrO}$ & 0.89 & $\mathrm{Lu}$ & $<0.3$ & Spinel & trace \\
$\mathrm{BaO}$ & 0.47 & $\mathrm{Cr}$ & 10.5 & Barite & trace \\
$\mathrm{Na}{ }_{2} \mathrm{O}$ & 0.03 & $\mathrm{Nb}$ & 225.0 & & \\
$\mathrm{~K}_{2} \mathrm{O}$ & 0.00 & $\mathrm{Rb}$ & 15.0 & & \\
$\mathrm{P}_{2} \mathrm{O}_{5}$ & 1.91 & $\mathrm{Sc}$ & 10.3 & & \\
$\mathrm{L.O} . \mathrm{O}$. & 35.8 & $\mathrm{Ta}$ & 6.0 & & \\
$\mathrm{Re}_{2} \mathrm{O}_{3}$ & 0.18 & $\mathrm{Zr}$ & $<10.0$ & & \\
$(\mathrm{Nb}, \mathrm{Ta})_{2} \mathrm{O}_{5}$ & 0.06 & & & & \\
\cline { 2 - 2 } Total & 99.1 & & & & \\
\hline
\end{tabular}

To solve this problem we obtained bulk chemical analyses of two replicate samples of the Husereau dike. Major and minor elements were analyzed by X-ray fluorescence (obtained through XRAL Ltd., Toronto, Canada), and trace elements were analyzed by instrumental neutron activation analysis (obtained through the Phoenix Memorial Laboratory, The University of Michigan). The Husereau dike (Table 1) is rich in $\mathrm{CaO}$ and $\mathrm{MgO}$, and markedly deficient in silica, the alkali metals, and zirconium. The nobium content is significantly higher than that of a typical marble, although much lower than the niobium content of other units of the Oka complex (see above references). Rare earth content is high, and shows the strong enrichment of light

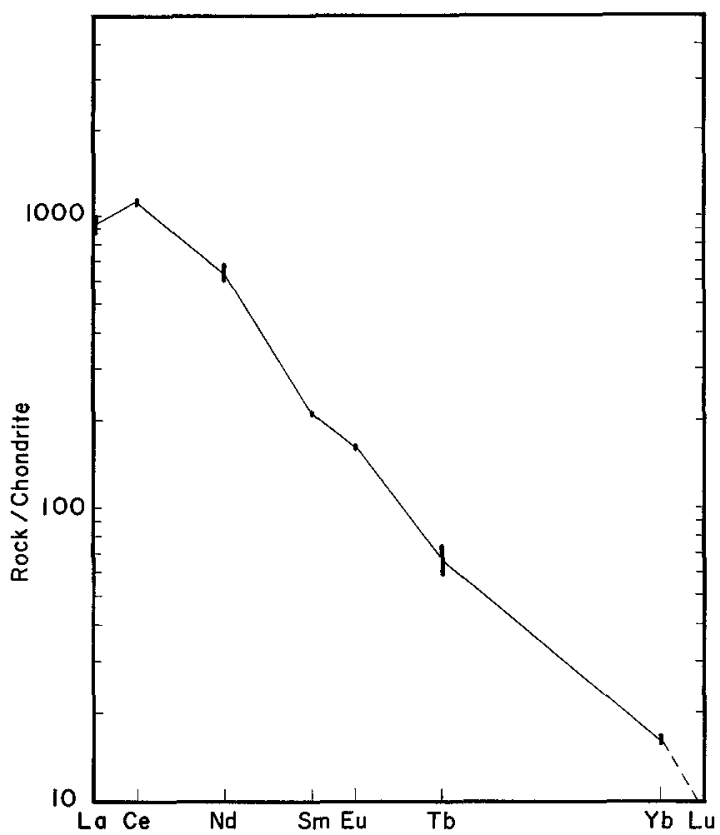

Fig. 2. Rare earth element abundances of Husereau dike rock, normalized to chondritic abundances. Bars show range of two replicate analyses.

Table 2. Oxide mineral analyses (see Appendix 2 for analytical procedure). Periclase (Pe) analysis normalized to 1 cation; spinel (Mt, MF) analyses normalized to 3 cations and $\mathrm{Fe}^{+2} / \mathrm{Fe}^{+3}$ adjusted to a charge sum of +8 by method of Bohlen and Essene (1977). Spinels MF 3.2 and MF 2.R are inferred to have grown at the eutectic. Magnetites are indicated as $\mathrm{Mt}$, magnesioferrites are indicated as $\mathrm{MF}$.

\begin{tabular}{lcrrrr}
\hline & Pe 1.1 & MF 3.2 & MF 2.R & Mt 1.2 & MF 4.C \\
\hline $\mathrm{TiO}_{2}$ & - & 0.36 & 0.07 & 0.00 & 0.51 \\
$\mathrm{Al}_{2} \mathrm{O}_{3}$ & - & 0.48 & 0.39 & 0.02 & 4.95 \\
$\mathrm{Cr}_{2} \mathrm{O}_{3}$ & - & 0.01 & 0.00 & 0.01 & 0.01 \\
$\mathrm{Fe}_{2} \mathrm{O}_{3}$ & - & 75.95 & 75.27 & 68.97 & 70.47 \\
$\mathrm{FeO}$ & 8.93 & 6.40 & 6.39 & 15.80 & 0.35 \\
$\mathrm{MnO}$ & 1.21 & 5.31 & 5.25 & 15.08 & 4.85 \\
$\mathrm{MgO}$ & 90.70 & 13.11 & 12.35 & 0.08 & 17.31 \\
\hline $\mathrm{Total}$ & 100.84 & 101.62 & 100.26 & 99.86 & 98.45 \\
$\mathrm{Ti}$ & - & 0.012 & 0.002 & 0.000 & 0.013 \\
$\mathrm{Al}$ & - & 0.020 & 0.015 & 0.001 & 0.196 \\
$\mathrm{Fe}$ & - & 1.956 & 1.981 & 1.999 & 1.778 \\
$\mathrm{Fe}$ & 0.052 & 0.190 & 0.202 & 0.504 & 0.010 \\
$\mathrm{Mn}$ & 0.007 & 0.154 & 0.156 & 0.491 & 0.138 \\
$\mathrm{Mg}$ & 0.941 & 0.671 & 0.644 & 0.005 & 0.865 \\
\hline
\end{tabular}

rare earths and absence of europium anomaly (Fig. 2) that is typical of carbonatites (Loubet et al. 1972; Eby 1975). There remains little doubt that the Husereau dike is a true carbonatite.

Mineralogically, the Husereau dike is quite unusual and contains many varieties rare to carbonatites. Periclase has been reported previously from Oka (Gold 1972), and the only other carbonatite occurrence is Kerimasi (Mariano and Roeder 1983). Manganese enrichment in magnetite reported in other units of the Oka complex (McMahon and Haggerty 1979) reaches an extreme in the Husereau dike, where the cores of some magnetite grains (associated with alabandite) approach jacobsite composition (Table 2). The 
Table 3. Sulfide mineral analyses (see Appendix 2 for analytical procedure). Alabandite (Alab) analyses normalized to 2 total atoms. Pyrrhotite (Pyrrh) analyses normalized to 1 sulfur atom.

\begin{tabular}{lcccc}
\hline & Alab 2A & Alab 2B & Pyrrh A2 & Pyrrh B3 \\
\hline $\mathrm{Fe}$ & 17.98 & 19.77 & 60.20 & 60.69 \\
$\mathrm{Mn}$ & 45.53 & 43.21 & 1.58 & 0.04 \\
$\mathrm{Mg}$ & 0.00 & 0.01 & 0.00 & 0.00 \\
$\mathrm{Zn}$ & 0.10 & 0.05 & 0.00 & 0.04 \\
$\mathrm{~S}$ & 36.73 & 36.58 & 38.55 & 38.55 \\
\hline Total & 100.34 & 99.62 & 100.33 & 99.32 \\
$\mathrm{Fe}$ & 0.280 & 0.310 & 0.896 & 0.904 \\
$\mathrm{Mn}$ & 0.721 & 0.690 & 0.024 & 0.001 \\
$\mathrm{Mg}$ & - & - & - & - \\
$\mathrm{Zn}$ & 0.001 & - & - & - \\
$\mathrm{S}$ & 0.997 & 1.000 & 1.000 & 1.000 \\
\hline
\end{tabular}

given analysis (Mt. 1.2) is the most Mn-rich magnetite found, and additional analyses will likely yield true jacobsites $\left(\mathrm{Mn}^{+2}>0.5\right.$ per formula unit). Jacobsitic magnetite grades outward to magnetite with $\mathrm{Mn}^{+2}=0.15$ per formula unit, and then to magnesioferrite (Table 2, MF.2R) essentially identical in composition to the small matrix magnesioferrites (Table 2, MF.3.2). The opaque oxide of the olivine spinel xenoliths is even closer to pure magnesioferrite $\left(\mathrm{Mg}^{+2}=0.86\right.$ per formula unit $)$ and is qualitatively similar to aluminous magnesioferrite from the Magnet Cove carbonatite complex (Harrington 1907; van de Pijpekamp et al. 1969). The high alumina content of the magnesioferrite reflects its coexistence with a spinel-hercynite solid solution. Another mineralogical oddity of the Husereau dike is the presence of alabandite (Table 3 ), which has been found only in one other carbonatite (Gittins and McKie 1980). The alabandite contains significant solid solution of $\mathrm{FeS}$, consistent with a high-temperature origin in equilibrium with pyrrhotite (Skinner and Luce 1971; Mann and van Vlack 1976; Fukuoka 1981).

\section{Vapor phase composition}

The mineral assemblage of the Husereau dike, calcite-dolomite-periclase-forsterite-apatite-magnesioferrite-pyrrhotitealabandite, is interpreted as a eutectic assemblage based on analogy with the experiments of Fanelli et al. (1981) and absence of reaction textures. The eutectic assemblage is exceptionally restrictive in constraining the composition of a coexisting fluid phase. If the temperature, total pressure, and fluid pressure are known, the assemblage buffers the fugacities of all gasses in the system C-O-H-S-F (Table 4). Most of the minerals in the Husereau dike are chemically homogeneous, and their compositions are used directly in thermochemical calculation. However, the carbonates and oxides are zoned. For carbonates, which are subject to rapid subsolidus re-equilibration, only core compositions are used in the following calculations. The opaque oxide phase has retained strong chemical zoning, which we interpret as reflecting an earlier igneous history, and thus only the compositions of the smallest grains or the rims of the larger grains are used in calculation.

Because the dike contains no primary hydrous minerals other than apatite, water fugacity (or partial pressure) cannot be calculated directly, and must be inferred from other
Table 4. Composition of the eutectic vapor phase in the Husereau dike, based on mineral equilibrium calculations. Prefered estimate of the eutectic temperature is $640^{\circ} \mathrm{C}$, and estimated uncertainty is $10^{\circ} \mathrm{C}$.

\begin{tabular}{|c|c|c|c|}
\hline & $630^{\circ} \mathrm{C}$ & $640^{\circ} \mathrm{C}$ & $650^{\circ} \mathrm{C}$ \\
\hline \multicolumn{4}{|c|}{ Partial pressures (bars) } \\
\hline $\begin{array}{l}\mathrm{H}_{2} \mathrm{O} \\
\mathrm{CO}_{2} \\
\mathrm{CO} \\
\mathrm{CH}_{4} \\
\mathrm{H}_{2} \\
\mathrm{H}_{2} \mathrm{~S}\end{array}$ & $\begin{array}{r}897.0 \\
95.0 \\
0.5 \\
0.2 \\
5.3 \\
2.5\end{array}$ & $\begin{array}{r}882.0 \\
110.0 \\
0.5 \\
0.1 \\
4.6 \\
2.7\end{array}$ & $\begin{array}{r}863.0 \\
130.0 \\
0.5 \\
0.1 \\
4.0 \\
2.6\end{array}$ \\
\hline \multicolumn{4}{|c|}{$\log _{10}$ fugacities } \\
\hline $\begin{array}{l}\mathrm{H}_{2} \mathrm{O} \\
\mathrm{CO}_{2} \\
\mathrm{O}_{2} \\
\mathrm{CO} \\
\mathrm{CH}_{4} \\
\mathrm{H}_{2} \\
\mathrm{~S}_{2} \\
\mathrm{H}_{2} \mathrm{~S} \\
\mathrm{SO}_{2} \\
\mathrm{~F}_{2} \\
\mathrm{HF}\end{array}$ & $\begin{array}{c}2.79 \\
2.08 \\
-19.1 \\
-0.17 \\
-0.48 \\
0.89 \\
-6.2 \\
0.46 \\
-5.1 \\
-44.8 \\
-5.77\end{array}$ & $\begin{array}{c}2.79 \\
2.15 \\
-18.6 \\
-0.13 \\
-0.76 \\
0.83 \\
-5.9 \\
0.49 \\
-4.7 \\
-43.9 \\
-5.63\end{array}$ & $\begin{array}{c}2.78 \\
2.22 \\
-18.2 \\
-0.09 \\
-1.04 \\
0.77 \\
-5.7 \\
0.47 \\
-4.4 \\
-43.1 \\
-5.45\end{array}$ \\
\hline
\end{tabular}

constraints. In light of the experimental work of Wyllie and Tuttle (1960) and our observations of ubiquitous alteration of periclase to brucite in the Husereau dike, it seems reasonable to infer that the dike was saturated with a waterbearing fluid. Therefore, we have calculated $\mathrm{P}\left(\mathrm{H}_{2} \mathrm{O}\right)$ as the difference between load pressure and the sum of the pressures of the other gases in C-O-H-S-F in the manner of Eugster and Skippen (1967), In the calculation, we assume that the partial pressures of $\mathrm{N}_{2}, \mathrm{Cl}_{2} \mathrm{He}$, Ar, etc. are negligible. Load pressure is estimated as $1 \mathrm{kbar}$ from inferred stratigraphy at emplacement (Gold 1966), consistent with the mineral assemblages in this and other units of the Oka complex (Treiman 1982).

In order to calculate gas fugacities, the eutectic temperature must be known, and two approaches are available for its estimation: mineral thermometry and extrapolation from experimental results in similar systems. The only calibrated mineral thermometer in the eutectic assemblage is calcite-dolomite (Graf and Goldsmith 1955, 1958; Goldsmith and Newton 1969; Rice 1977), although Gittins (1979) cautions against its general application to carbonatites because the thermometer resets rapidly in fluid-rich environments. Coexisting calcite and dolomite from the $\mathrm{Hu}$ sereau dike are close to the join $\mathrm{CaCO}_{3}-\mathrm{CaMg}\left(\mathrm{CO}_{3}\right)_{2}$ (Table 5), and the calcite-dolomite solvus is applicable as a potential geothermometer. Using the thermometric formula of Rice (1977), calcite and dolomite from the Husereau dike yield temperatures between 450 and $575^{\circ} \mathrm{C}$. Anovitz and Essene (1982) and Essene (1982) have fitted a solvus location to most of the reversed experimental data in $\mathrm{CaCO}_{3}-\mathrm{CaMg}\left(\mathrm{CO}_{3}\right)_{2}$, and thermometry using this revised solvus yields a temperature range of $540-610^{\circ} \mathrm{C}$ (Table 5). Calcite is less magnesian near grain boundaries with dolomite, suggesting some subsolidus diffusion and re-equilibration. The core compositions may also have been affected by re-equilibration, so the temperatures must also be regarded as minima (Gittins 1979). The effect of strontium 
Table 5. Carbonate mineral analyses (calcite, $\mathrm{Cc}$; dolomite, Do; see Appendix 2 for analytical procedure) and normalizations to 2 cations. The first six analyses are a traverse (100 microns length) from the center of a calcite grain (Cc 1.1) to the center of an adjacent dolomite (Do 1.1). Cc 1.3 is closest to grain boundary, and is depleted in $\mathrm{Mg}$ relative to $\mathrm{Cc} 1.1$, suggesting some subsolidus re-equilibration. Cc 2.1 and Do 2.1 are core compositions. Temperatures calculated from the thermometric calibration of Anovitz and Essene (1982)

\begin{tabular}{|c|c|c|c|c|c|c|c|c|}
\hline & Ce 1.1 & Cc 1.2 & Cc 1.3 & Do 1.3 & Do 1.2 & Do 1.1 & Cc 2.1 & Do 2.1 \\
\hline $\mathrm{FeO}$ & 0.03 & 0.06 & 0.07 & 0.05 & 0.17 & 0.18 & 0.20 & 0.10 \\
\hline $\mathrm{MnO}$ & 0.60 & 0.65 & 0.57 & 0.79 & 0.81 & 0.61 & 0.53 & 0.88 \\
\hline $\mathrm{MgO}$ & 2.51 & 2.16 & 1.95 & 21.28 & 20.93 & 20.98 & 2.38 & 21.11 \\
\hline $\mathrm{CaO}$ & 50.52 & 51.64 & 51.34 & 30.07 & 29.74 & 29.84 & 50.92 & 30.11 \\
\hline $\mathrm{SrO}$ & 1.97 & 1.78 & 2.10 & 0.67 & 0.70 & 0.73 & 1.97 & 0.64 \\
\hline $\mathrm{BaO}$ & 0.61 & 0.23 & 0.49 & 0.07 & 0.11 & 0.00 & 0.54 & 0.16 \\
\hline $\mathrm{CO}_{2}$ & 43.79 & 44.14 & 43.85 & 47.63 & 47.10 & 47.10 & 44.00 & 47.57 \\
\hline Total & 100.03 & 100.66 & 100.37 & 100.56 & 99.56 & 99.44 & 100.54 & 100.57 \\
\hline $\mathrm{Fe}$ & 0.001 & 0.001 & 0.001 & 0.001 & 0.001 & 0.002 & 0.003 & 0.001 \\
\hline $\mathrm{Mn}$ & 0.009 & 0.009 & 0.008 & 0.010 & 0.011 & 0.008 & 0.007 & 0.011 \\
\hline $\mathrm{Mg}$ & 0.063 & 0.053 & 0.048 & 0.488 & 0.485 & 0.486 & 0.059 & 0.484 \\
\hline $\mathrm{Ca}$ & 0.905 & 0.918 & 0.919 & 0.495 & 0.495 & 0.497 & 0.908 & 0.497 \\
\hline $\mathrm{Sr}$ & 0.019 & 0.017 & 0.020 & 0.006 & 0.006 & 0.007 & 0.019 & 0.006 \\
\hline $\mathrm{Ba}$ & 0.004 & 0.001 & 0.003 & 0.000 & 0.001 & 0.000 & 0.004 & 0.001 \\
\hline $\mathrm{C}$ & 1.000 & 1.000 & 1.000 & 1.000 & 1.000 & 1.000 & 1.000 & 1.000 \\
\hline $\mathrm{T}\left({ }^{\circ} \mathrm{C}\right)$ & 610 & 566 & 540 & & & & 588 & \\
\hline
\end{tabular}

content on the calcite-dolomite solvus is not known, but (based on ionic size arguments) it seems likely that magnesium solubility in calcite decreases as strontium content increases, and temperatures derived for strontian calcite-dolomite pairs would also be minima.

Experimental studies in similar systems provide another constraint on the eutectic temperature of the Husereau dike. In the system $\mathrm{CaO}-\mathrm{MgO}-\mathrm{CO}_{2}-\mathrm{H}_{2} \mathrm{O}$, Fanelli et al. (1981) found the eutectic assemblage calcite-dolomite-periclase-melt-vapor at $660^{\circ} \mathrm{C}$ and $2 \mathrm{kbar}$. This eutectic temperature can be extrapolated to $1 \mathrm{kbar}$ (the estimated emplacement pressure) by assuming that the P-T slope of the melting reaction is similar to those of other eutectic reactions in similar experimental systems. Eutectic melting curves in $\mathrm{CaO}-\mathrm{MgO}-\mathrm{SiO}_{2}-\mathrm{CO}_{2}-\mathrm{H}_{2} \mathrm{O}$ generally have slopes of $-25^{\circ} \mathrm{C} / \mathrm{kbar}$ in the range $1-2 \mathrm{kbar}$ (Wyllie and Tuttle 1960; Wyllie and Haas 1965; Boettcher and Wyllie 1969; Boettcher et al. 1980), and thus the calcite-dolomite-periclase-melt-vapor eutectic is estimated as $685^{\circ} \mathrm{C} 1 \mathrm{kbar}$. Addition of $\mathrm{P}_{2} \mathrm{O}_{5}$ lowers the $\mathrm{CaCO}_{3}-\mathrm{Ca}(\mathrm{OH})_{2}$-melt-vapor eutectic temperature by approximately $35^{\circ} \mathrm{C}$ (Wyllie and Tuttle 1960; Wyllie and Biggar 1966), and addition of $\mathrm{SiO}_{2}$, $\mathrm{FeO}$, and $\mathrm{Fe}_{2} \mathrm{O}_{3}$ is estimated to lower the eutectic temperature an additional $10^{\circ} \mathrm{C}$. Thus, we have taken the eutectic temperature for the Husereau dike carbonatite as $640 \pm 10^{\circ} \mathrm{C}$, consistent with the minimum temperature estimated from calcite-dolomite thermometry.

Knowing the pressure and temperature of eutectic crystallization of the Husereau carbonatite dike, the fugacities (and therefore the partial pressures) of gases in the volatile phase can be calculated (Table 5) from mineral buffer reactions by the thermodynamic equation of equilibrium:

\section{$0=\Delta \mathrm{G}^{\mathrm{P}}{ }_{\mathrm{T} 2}(\mathrm{rxn})=\Delta \mathrm{G}^{\circ}{ }_{\mathrm{T} 1}(\mathrm{rxn})+\Delta \mathrm{V}(\mathrm{rxn}) \mathrm{dP}-\Delta \mathrm{S}(\mathrm{rxn}) \mathrm{dT}+$ $\mathrm{RT} \ln \mathrm{K}$}

where $\Delta \mathrm{G}^{\circ}(\mathrm{rxn})$ is the free energy of the reaction in the standard state. The activity (or fugacity) ratio $\mathrm{K}$ is given by:
$\mathrm{K}=\left(a_{1}{ }^{\mathrm{n} 1} \cdot a_{2}{ }^{\mathrm{n} 2} \cdot \ldots / a_{3}{ }^{\mathrm{n} 3} \cdot a_{4}{ }^{\mathrm{n} 4} \cdot \ldots\right)$

where $a_{i}$ is the activity (or fugacity) of a species in the reaction, and $n_{i}$ is its stoichiometric coefficient in the reaction. Calculations were either performed manually or with the computer program EQUILI, similar to that described by Slaughter et al. (1976). The program calculates the free energy of a given reaction at specified $\mathrm{P}, \mathrm{T}, a\left(\mathrm{CO}_{2}\right)$, or $a\left(\mathrm{H}_{2} \mathrm{O}\right)$, given the entropies, thermal expansions, and compressibilities of the participant solid phases, and the free energy of the reaction at a reference pressure and temperature. Mineral entropies and the free energies of reaction are from Robie et al. (1979) and Treiman and Essene (1983) unless otherwise noted, and thermal expansion and compressibility values are from Clark (1966). The free energy of $\mathrm{H}_{2} \mathrm{O}$ is from Burnham et al. (1969), and the free energy of $\mathrm{CO}_{2}$ is from Vuklovich and Altunin (1965). Fugacity coefficients for $\mathrm{H}_{2} \mathrm{O}-\mathrm{CO}_{2}$ mixtures are from Kerrick and Jacobs (1981), and the fugacity coefficients for other gas species are from Ryzhenko and Volkov (1971) and Shmulovich et al. (1982) as noted below. Fugacity coefficients and calculated gas fugacities were then used to derive partial pressures of gas species (Eugster and Skippen 1967). Because $\mathrm{H}_{2} \mathrm{O}$ pressure is calculated as the difference between the sum of other gas pressures and load pressure, and because some other gas pressures are dependent on $\mathrm{H}_{2} \mathrm{O}$ pressure, a method of successive approximation was used to determine the appropriate $\mathrm{P}\left(\mathrm{H}_{2} \mathrm{O}\right)$.

In the eutectic assemblage of the Husereau dike, the fugacity of $\mathrm{CO}_{2}, f\left(\mathrm{CO}_{2}\right)$, is buffered by the reaction

$\mathrm{CaMg}\left(\mathrm{CO}_{3}\right)_{2}=\mathrm{CaCO}_{3}+\mathrm{MgO}+\mathrm{CO}_{2}$

dolomite $=$ calcite + periclase + vapor,

located by Harker and Tuttle (1955) for $\mathrm{X}\left(\mathrm{CO}_{2}\right)=1.0$. Thermodynamic calculations are consistent with their experimental determination of reaction (1) near $820^{\circ} \mathrm{C}$ at $1 \mathrm{kbar}$. The location of (1) for a mixed $\mathrm{CO}_{2}-\mathrm{H}_{2} \mathrm{O}$ gas phase (Fig. 3) was calculated with the fugacity coefficients of Kerrick and Jacobs (1981). 


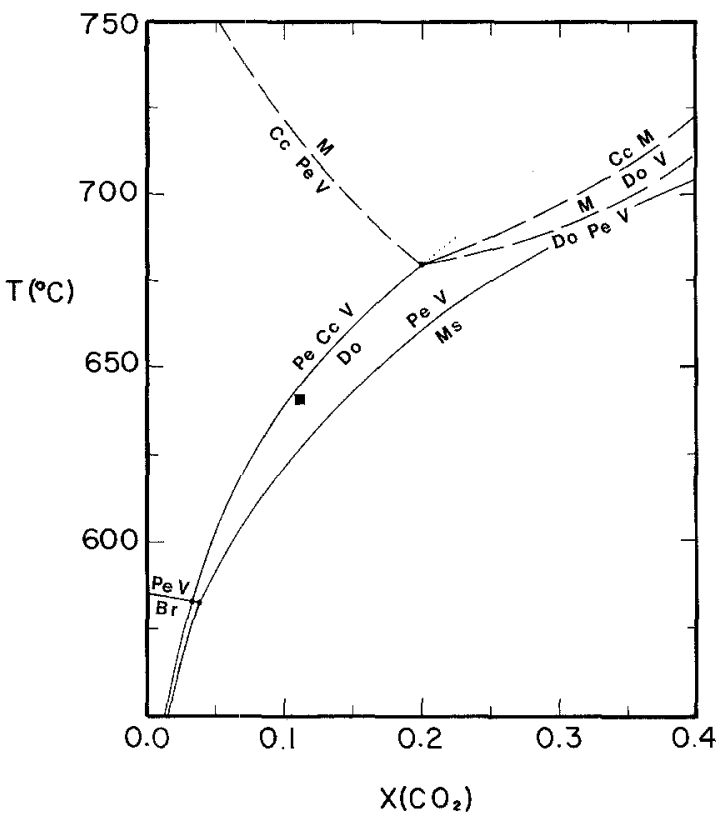

Fig. 3. Calculated phase equilibria relevant to the calcite-dolomitepericlase-melt-vapor eutectic, at $1 \mathrm{kbar}$ vapor pressure. Vapor phase is assumed to contain only $\mathrm{H}_{2} \mathrm{O}$ and $\mathrm{CO}_{2}$, with fugacity coefficients from Kerrick and Jacobs (1981). Locations of melting relations are hypothetical, but consistent with the results of Fanelli et al. (1981). Abbreviations are: Cc, calcite; Do, dolomite; Pe, periclase; Ms, magnesite; $\mathrm{Br}$, brucite; $\mathrm{M}$, melt; and V, vapor. Filled square is at $\mathrm{T}$ and $\mathrm{X}\left(\mathrm{CO}_{2}\right)$ inferred for the Husereau dike eutectic.

To apply reaction (1) to the Husereau dike, the solidphase activities must be correct for solid solutions in the natural minerals. We have used ideal ionic models (e.g., Saxena 1973) for the activities of calcite and periclase so that, for instance, the activity of $\mathrm{CaCO}_{3}$ in calcite is estimated as $\mathrm{X}(\mathrm{Ca})$. Because the calcite and periclase are close to end-member compositions (Table 2,5), only small errors will be introduced by the assumption of ideal ionic models and the values adopted for this calculation are $a(\mathrm{Cc})=0.91$ and $a(\mathrm{Pe})=0.94$. Dolomite is close to end-member composition (Table 5), and because dolomite activities show strong positive deviation from ideality (Anovitz and Essene 1982 , we have used $a(\mathrm{Dol})=1.0$. When applied in reaction (1), these values yield $f\left(\mathrm{CO}_{2}\right)=140 \pm 20$ bars. The partial pressure of carbon dioxide is $110 \pm 20$ bars, consistent with the absence of primary brucite in the Husereau dike (Fig. 3 , Table 4).

The oxygen fugacity of the Husereau dike eutectic is important in its own right and is needed to calculate the fugacities of other gases in C-O-H-S. Because the dike contains olivine, a magnetite solid solution, and an assemblage (olivine-periclase) that buffers silica activity, the quartzfayalite-magnetite (QFM) oxygen buffer,

$3 \mathrm{Fe}_{2} \mathrm{SiO}_{4}+\mathrm{O}_{2}=2 \mathrm{Fe}_{3} \mathrm{O}_{4}+3 \mathrm{SiO}_{2}$ fayalite + oxygen $=$ magnetite + quartz,

may be applied (Wones and Gilbert 1969; Hewitt 1978). Oxygen fugacity can be calculated from (2) $\left(\mathrm{S}_{298.15 \mathrm{~K}}^{0}\right.$ for fayalite from Essene et al. 1980, and Robie et al. 1982), once the activities of quartz, fayalite, and magnetite are determined.

The activity of silica can be calculated directly from the reaction
Table 6. Olivine analyses (see Appendix 2 for analytical procedure) and normalizations to 3 cations.

\begin{tabular}{lrrr}
\hline & B1A & B1B & \multicolumn{1}{c}{ B2 } \\
\hline $\mathrm{SiO}_{2}$ & 43.21 & 43.13 & 43.19 \\
$\mathrm{FeO}$ & 1.04 & 1.10 & 1.16 \\
$\mathrm{MnO}$ & 1.17 & 1.21 & 1.24 \\
$\mathrm{MgO}$ & 54.89 & 55.06 & 55.10 \\
$\mathrm{CaO}$ & 0.14 & 0.10 & 0.08 \\
\hline Total & 100.45 & 100.60 & 100.77 \\
$\mathrm{Si}$ & 1.020 & 1.017 & 1.017 \\
$\mathrm{Fe}$ & 0.021 & 0.022 & 0.023 \\
$\mathrm{Mn}$ & 0.023 & 0.024 & 0.025 \\
$\mathrm{Mg}$ & 1.932 & 1.935 & 1.934 \\
$\mathrm{Ca}$ & 0.004 & 0.002 & 0.002 \\
\hline
\end{tabular}

$\mathrm{Mg}_{2} \mathrm{SiO}_{4}=2 \mathrm{MgO}+\mathrm{SiO}_{2}$

forsterite $=$ periclase + silica,

adjusted for the solid solutions of $\mathrm{Mg}_{2} \mathrm{SiO}_{4}$ in olivine and $\mathrm{MgO}$ in periclase. Both minerals are close to their endmembers (Tables 2, 6), allowing reasonable estimation of activities with ideal ionic solution models. The estimated $a\left(\mathrm{Mg}_{2} \mathrm{SiO}_{4}\right)=0.94$ and $a(\mathrm{MgO})=0.94$ yield $a\left(\mathrm{SiO}_{2}\right)=$ $7.8 \times 10^{-4}$, or $\log a\left(\mathrm{SiO}_{2}\right)=-3.11 \pm 0.04$.

Fayalite activity in olivine solid solutions is given by the semi-empirical formulation of Engi (1980), who modelled the forsterite-fayalite join as a regular solution with temperature-dependent parameters. Engi did not consider the effect of $\mathrm{Mn}$ on fayalite activity, and we have assumed that $\mathrm{Mg}$ and $\mathrm{Mn}$ have identical effects. Typical eutectic olivine from the Husereau dike has $\mathrm{X}(\mathrm{Fe})=0.011$ (Table 6), for which $\gamma\left(\mathrm{FeSi}_{0.5} \mathrm{O}_{2}\right)=1.41$ (Engi 1980) and $a\left(\mathrm{Fe}_{2} \mathrm{SiO}_{4}\right)=$ $(1.41 \times 0.011)^{2}=2.41 \times 10^{-4}$. Lacking data on activity-composition relations in the magnetite-magnesioferrite solid solution near $650^{\circ} \mathrm{C}$, we have assumed that the solid solution is ideal, and derive $a\left(\mathrm{Fe}_{3} \mathrm{O}_{4}\right)=0.186$ (MF 3.2, 2.R; Table 2).

Substituting the activities of $\mathrm{Fe}_{2} \mathrm{SiO}_{4}, \mathrm{SiO}_{2}$, and $\mathrm{Fe}_{3} \mathrm{O}_{4}$ into the QFM oxygen buffer calculation gives the eutectic oxygen fugacity of the Husereau dike as $0.05 \pm 0.10 \log$ units greater than QFM. Considering the errors possible in estimating the component activities, this value is indistinguishable from QFM.

The numerical value of oxygen fugacity to be used in further calculations depends on which calibration of the QFM buffer is chosen. The experimental determinations of Wones and Gilbert (1969), Hewitt (1978), and Myers and Eugster (1983) all include carefully reversed experiments, yet those of Wones and Gilbert (1969) do not agree with the later measurements. Thermodynamic data for magnetite and fayalite are too imprecise to differentiate between the experiments (Robie et al. 1982), and variability in the minerals themselves (e.g., $\mathrm{Fe}^{+3}$ in fayalite or zeropoint entropy in magnetite) may, in part, explain the difference between the experiments. Following the suggestion of Robie et al. (1982), we have used the QFM calibration of Hewitt (1978) which is identical within error to that of Myers and Eugster (1983), and derive $\log f\left(\mathrm{O}_{2}\right)=-18.6 \pm$ 0.4 for the eutectic.

An independent confirmation of this calculated oxygen fugacity comes from the experimentally determined equilib- 
rium between magnesioferrite-magnetite and periclase-wüstite solid solutions (Katsura and Kimura 1965; Speidel 1967). The compositions of these solid solutions in $\mathrm{Fe}-$ $\mathrm{Mg}-\mathrm{O}$ is a function of oxygen fugacity, and both groups of workers have determined "periclase" and "magnesioferrite" compositions as functions of $f\left(\mathrm{O}_{2}\right)$ at $1,160^{\circ}$ and $1,300^{\circ} \mathrm{C}$ respectively. Speidel (1967) also combined his results with those of Katsura and Kimura (1965) in a plot of isopleths of magnesioferrite/magnetite compositions in $f\left(\mathrm{O}_{2}\right)$-T space. The data of Shishkov et al. (1980) are excluded from our analysis because they do not provide reasonable composition isopleths when combined with the remaining data. We have recast the magnesioferrite-magnetite isopleths in terms of $\mathrm{X}(\mathrm{FeO})$, and have extrapolated the isopleths to the eutectic temperature for the Husereau dike (Fig. 4). From the composition of the eutectic magnetite (Table 2), Figure 4 implies that the eutectic $f\left(\mathrm{O}_{2}\right)$ was $10^{-18.7}$, as compared to $10^{-18.6}$ calculated from the QFM buffer. The close correspondence of the inferred and calculated $f\left(\mathrm{O}_{2}\right)$ values lends support to the ideal activity model employed for the magnetite-magnesioferrite solid solution, and to the calculated oxygen fugacity.

The fugacity of carbon monoxide can be calculated from the fugacities of oxygen and carbon dioxide by the reaction

$2 \mathrm{CO}_{2}=2 \mathrm{CO}+\mathrm{O}_{2}$,

yielding $f(\mathrm{CO})=0.5$ bars. Ryzhenko and Volkov (1971) give the fugacity coefficient for pure $\mathrm{CO}$ at $640^{\circ} \mathrm{C}, 1 \mathrm{kbar}$ as 1.41, and (lacking other data) we have applied that coefficient to the reduced $\mathrm{CO}$ activity of the Husereau dike.

The fugacities and pressures of hydrogen gas and methane (Table 4) may be calculated from the equilibria

$$
\begin{aligned}
& 2 \mathrm{H}_{2} \mathrm{O}=2 \mathrm{H}_{2}+\mathrm{O}_{2} \text {, and } \\
& \mathrm{CO}_{2}+2 \mathrm{H}_{2} \mathrm{O}=\mathrm{CH}_{4}+2 \mathrm{O}_{2},
\end{aligned}
$$

given the values of $f\left(\mathrm{O}_{2}\right)$ and $f\left(\mathrm{CO}_{2}\right)$ calculated above, and the assumption that $\mathrm{P}\left(\mathrm{H}_{2} \mathrm{O}\right)$ equals load pressure minus the partial pressures of the other gas species in $\mathrm{C}-\mathrm{O}-\mathrm{H}-\mathrm{S}-\mathrm{F}$. Calculation of the fugacities and pressures is an iterative procedure, in which $\mathrm{P}\left(\mathrm{H}_{2} \mathrm{O}\right)$ (used to calculate partial pressures of $\mathrm{H}_{2}, \mathrm{CH}_{4}$, and $\mathrm{H}_{2} \mathrm{~S}$ ) is adjusted until the total pressure from all gas species equals load pressure (1 kbar). Fugacity coefficients for $\mathrm{H}_{2} \mathrm{O}-\mathrm{CO}_{2}$ mixtures are from Kerrick and Jacobs (1981), and fugacity coefficients for $\mathrm{CH}_{4}$ and $\mathrm{H}_{2}$ in water-rich vapor are from Shmulovich et al. (1982).

Sulfur fugacity in the Husereau dike can be determined directly from the composition of the eutectic pyrrhotite ( $\mathrm{Ta}-$ ble 3; Toulmin and Barton 1964), or from the quartz-fayalite-magnetite-pyrrhotite equilibrium (QFMP)

$$
\begin{aligned}
& 4 \mathrm{Fe}_{2} \mathrm{SiO}_{4}+\mathrm{S}_{2}=2 \mathrm{Fe}_{3} \mathrm{O}_{4}+2 \mathrm{FeS}+4 \mathrm{SiO}_{2}, \\
& \text { fayalite + sulfur }=\text { magnetite }+ \text { pyrrhotite }+ \text { silica, }
\end{aligned}
$$

using activities of magnetite, fayalite, and quartz derived above, and FeS activity calculated from Toulmin and Barton (1964). Ignoring the variable Mn-content of the pyrrhotites (Table 3), these two approaches give widely divergent values: QFMP yields $\log f\left(\mathrm{~S}_{2}\right)=-7.0$, and Toulmin and Barton's (1964) calibration yields $\log f\left(\mathrm{~S}_{2}\right)=-3.7$. Because pyrrhotite is quite susceptible to low-temperature re-equilibration (vis. Barton 1970), the discrepancy in $f\left(\mathrm{~S}_{2}\right)$ may arise from subsolidus sulfidation (or iron depletion) of the pyrrhotite. This process is likely in that secondary pyrite

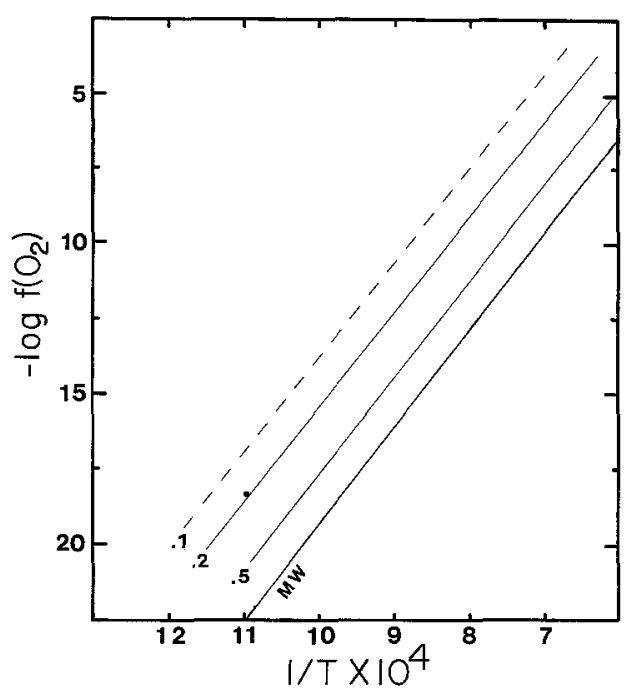

Fig. 4. Isopleths of $X(\mathrm{FeO})$ in magnetite-magnesioferrite solid solution coexisting with magnesiowüstite solid solution. Graph is recast from Speidel (1967), and extrapolated below $1,160^{\circ} \mathrm{C}$ $\left(=7.0 \times 10^{-4} \mathrm{~K}^{-1}\right)$. The magnetite-wüstite equilibrium, $\mathrm{X}(\mathrm{FeO})=$ 1.0 , is from Lindsley (1976). Dot is at the T, X (FeO) for rim and matrix grain magnetite-magnesioferrite compositions inferred to have grown at the eutectic. See text for discussion of oxygen fugacities.

Table 7. Apatite analyses (see Appendix 2 for analytical procedures), and normalizations to 8 cations. $\mathrm{H}_{2} \mathrm{O}$ and $\mathrm{OH}$ are calculated from stoichiometry, so that $\mathrm{F}+\mathrm{Cl}+\mathrm{OH}=1.0$

\begin{tabular}{lrrr}
\hline & \multicolumn{1}{l}{ } & \multicolumn{1}{l}{$3 \mathrm{a}$} \\
\hline $\mathrm{CaO}$ & 55.33 & 55.36 & 55.43 \\
$\mathrm{SrO}$ & 1.02 & 1.02 & 0.97 \\
$\mathrm{P}_{2} \mathrm{O}_{5}$ & 41.29 & 41.55 & 42.47 \\
$\mathrm{As}_{2} \mathrm{O}_{5}$ & 0.00 & 0.04 & 0.00 \\
$\mathrm{~F}_{2}$ & 2.85 & 2.88 & 2.93 \\
$\mathrm{Cl}_{2}$ & 0.00 & 0.00 & 0.02 \\
$\mathrm{H}_{2} \mathrm{O}$ & 0.43 & 0.41 & 0.40 \\
\hline $\mathrm{Total}$ & 100.92 & 101.26 & 102.22 \\
$2 \mathrm{~F}=\mathrm{O}$ & -1.20 & -1.22 & -1.23 \\
\hline $\mathrm{Total}$ & 99.72 & 100.04 & 100.99 \\
$\mathrm{Ca}$ & 5.001 & 4.989 & 4.954 \\
$\mathrm{Sr}$ & 0.050 & 0.050 & 0.047 \\
$\mathrm{P}$ & 2.949 & 2.959 & 2.999 \\
$\mathrm{As}$ & 0.000 & 0.002 & 0.000 \\
$\mathrm{~F}$ & 0.759 & 0.768 & 0.773 \\
$\mathrm{Cl}$ & 0.000 & 0.000 & 0.002 \\
$\mathrm{OH}$ & 0.241 & 0.232 & 0.225 \\
\hline
\end{tabular}

replaces pyrrhotite in the Husereau dike. Because neither method of calculating sulfur fugacity may be applied without knowledge of pyrrhotite composition, we have assumed that, at the eutectic, both reaction (7) and the method of Toulmin and Barton (1964) would yield the same sulfur fugacity. For the eutectic of $640^{\circ} \mathrm{C}$ and $1 \mathrm{kbar}$, a pyrrhotite composition of $\mathrm{N}_{\mathrm{Fe}}=0.967$ yields $f\left(\mathrm{~S}_{2}\right)=10^{-5.9}$ bars in both calculations, and that value has been used in all subsequent calculations. The fugacity of sulfur gas in also buffered by the reaction 
$2 \mathrm{~S}_{2}+2 \mathrm{MgFe}_{2} \mathrm{O}_{4}=2 \mathrm{MgO}+4 \mathrm{FeS}+3 \mathrm{O}_{2}$

sulfur + magnesioferrite $=$ periclase + pyrrhotite + oxygen

given the oxygen fugacity determined above. The FeS activity is from the pyrrhotite composition and the calibration of Toulmin and Barton (1964), and $\mathrm{MgO}$ and $\mathrm{MgFe}_{2} \mathrm{O}_{4}$ activities are as described above. Reaction 8 yields sulfur fugacities slightly lower ( $0.2 \mathrm{log}$ units) than the QFMP and Toulmin and Barton pyrrhotite method; considering the uncertainties in original pyrrhotite composition and in $\mathrm{MgFe}_{2} \mathrm{O}_{4}$ activity, all three methods (reaction 7 , reaction 8 , and Toulmin and Barton) are in reasonable agreement. Fugacities of other sulfur-bearing species are calculated from gas-phase equilibria, and the partial pressure of $\mathrm{H}_{2} \mathrm{~S}$ is calculated using the activity coefficients of Ryzhenko and Volkov (1971).

Given the water fugacity calculated above, the fugacities of fluorine-bearing gas species in C-O-H-S-F can be calculated from the equilibrium

$\mathrm{Ca}_{5}\left(\mathrm{PO}_{4}\right)_{3}(\mathrm{OH})+\mathrm{HF}=\mathrm{Ca}_{5}\left(\mathrm{PO}_{4}\right)_{3} \mathrm{~F}+\mathrm{H}_{2} \mathrm{O}$

hydroxyl-apatite $+\mathrm{HF}=$ fluor-apatite + water,

and vapor-vapor equilibria. Free energy of hydrogen fluoride is from Stull and Prophet (1974), free energy of fluorapatite is from Westrich and Navrotsky (1981), and free energies for water and hydroxyl-apatite are from Robie et al. (1979). Husereau dike apatites are fluorine-rich (Table 7), and the hydroxyl is calculated from charge-balance. The apatites have $\mathrm{X}(\mathrm{F})=0.763$, and (lacking thermodynamic data on the apatite solid solution) we have assumed an ideal ionic model for the apatite, giving $a$ (fluorap) $=$ $0.763 \pm .005$ and $a$ (hydroxyl-ap) $=0.237 \pm .005$. These values imply that $\log f(\mathrm{HF})=-5.6 \pm 0.1$ and $\log f\left(\mathrm{~F}_{2}\right)=-$ $43.9 \pm 1$ (Table 4).

\section{Discussion}

The eutectic vapor phase of the Husereau dike was essentially a water-rich $\mathrm{H}_{2} \mathrm{O}-\mathrm{CO}_{2}$ fluid with $\mathrm{X}\left(\mathrm{H}_{2} \mathrm{O}\right)+$ $\mathrm{X}\left(\mathrm{CO}_{2}\right)>0.99$ and $\mathrm{X}\left(\mathrm{CO}_{2}\right)$ near 0.1 (Table 4). Methane, carbon monoxide, and hydrogen had low but significant partial pressures, and partial pressures of the other gas species were negligible. Oxygen fugacity was near the quartzfayalite-magnetite buffer, which, when combined with the calculated $\mathrm{CO}_{2}$ fugacity, is compatible with the absence of graphite. Sulfur fugacity was near the quartz-fayalitemagnetite-pyrrhotite buffer, consistent with the absence of primary pyrite or hauerite. Fluorine fugacity was low, and compatible with the absence of fluorite or other fluoride phases besides apatite.

The calculated gas phase composition (Table 4) is compatible with the experimental results of Wyllie and Tuttle (1960) and subsequent workers, all of whom found that a water-rich fluid is necessary to reduce the melting point of carbonate to geologically reasonable temperatures. Rankin $(1975,1977)$ found water-rich fluid inclusions in carbonatite minerals and inferred that the fluid phase of the carbonatite magma was also water-rich, but the present work is the first calculation of the full vapor phase composition of a carbonatite. We find, as did Rankin $(1975,1977)$, that the vapor phase was rich in $\mathrm{H}_{2} \mathrm{O}$, and we conclude that the experiments of Wyllie and Tuttle (1960) and others are indeed relevant to natural carbonatites. The Husereau dike is, however, unique and its gas phase may not be like those of other carbonatites.

It is not possible to use phase equilibrium methods alone to trace the chemical evolution of the carbonatitic vapor phase, because the last phase to crystallize at the eutectic (periclase; Fanelli et al. 1981) is essential in the gas calculations. Above the eutectic temperature and therefore in the absence of periclase, reaction (1) provides only a lower limit on the fugacity of carbon dioxide (Fig. 3). The location of reaction (1) also shifts to higher $\mathrm{CO}_{2}$ fugacity with increasing temperature (Table 4), and the carbonatitic vapor phase must have been enriched in $\mathrm{CO}_{2}$ at temperatures above the eutectic.

Unfortunately, the data available in published experiments on carbonatites do not allow calculation of the gas phase composition. In most such experiments (e.g., Wyllie and Tuttle 1960; Boettcher and Wyllie 1969; Fanelli et al. 1981) the vapor phase falls in the trivariant system $\mathrm{C}-\mathrm{O}-\mathrm{H}$ (ignoring $\mathrm{SiO}_{2}, \mathrm{MgO}, \mathrm{CaO}$, etc. dissolved in the vapor) with insufficient constraints for complete definition of the fugacities (or partial pressures) of the gas species. For example, in the system $\mathrm{CaO}-\mathrm{CO}_{2}-\mathrm{H}_{2} \mathrm{O}$, the eutectic assemblage calcite-portlandite-vapor-melt (Wyllie and Tuttle 1960) buffers the composition of the vapor phase by the reaction

$\mathrm{CaCO}_{3}+\mathrm{H}_{2} \mathrm{O}=\mathrm{Ca}(\mathrm{OH})_{2}+\mathrm{CO}_{2}$ calcite + water $=$ portlandite $+\mathrm{CO}_{2}$,

which provides one constraint on the system C-O-H. A second constraint is that the sum of the partial pressures of all gas species must equal load pressure, but no third constraint is available. If oxygen fugacity, for instance, were known, it would be possible to calculate the composition of the vapor phase in C-O-H. If one assumes that the $f\left(\mathrm{O}_{2}\right)$ was near the $\mathrm{Ni}-\mathrm{NiO}$ buffer at $\mathrm{P}($ total $)=1 \mathrm{kbar}$ and $\mathrm{T}=$ $675^{\circ} \mathrm{C}$, one may calculate $\mathrm{P}\left(\mathrm{H}_{2} \mathrm{O}\right)=996$ bars, $\mathrm{P}\left(\mathrm{H}_{2}\right)=$ 2.5 bars and $\mathrm{P}\left(\mathrm{CO}_{2}\right)=1$ bar for the calcite-portlandite assemblage. Similar calculations can be made for the systems $\mathrm{Ca}-\mathrm{Si}-\mathrm{C}-\mathrm{O}-\mathrm{H}$ and $\mathrm{Ca}-\mathrm{Mg}-\mathrm{C}-\mathrm{O}-\mathrm{H}$ when the vapor is in equilibrium with three solid phases. Buffered experiments and/ or direct measurements of fluid or liquid compositions are needed to fully characterize these more complicated systems.

\section{Appendix 1: Petrography}

The periclase carbonatite (sample $80 \mathrm{H1}$ ) consists mostly of carbonate minerals, with calcite predominant over dolomite (alizarin red $\mathrm{S}$ stain was used to distinguish carbonate minerals). Dolomite forms squat euhedra (possibly phenocrysts) averaging $0.5 \times 0.25 \mathrm{~mm}$, and ranging up to $1.5 \times 1.0 \mathrm{~mm}$. The crystals commonly exhibit undulose extinction, but are rarely divided into subgrains. Larger dolomites contain discontinuous twin lamellae (strain-induced?), best developed near included silicate, oxide, or phosphate crystals. Dolomites (particularly those near or in the darker, altered bands) are commonly clouded by myriad minute inclusions along healed fractures. Calcite is present only as anhedral grains averaging $0.7 \mathrm{~mm}$ diameter, and forms the matrix for all other minerals. Calcite invariably contains high densities of twin lamellae, themselves commonly curved. The twin lamellae (strain-induced?) are most evident near oxide, silicate, or phosphate grains.

Periclase and magnetite-magnesioferrite are the only oxide minerals outside of the xenoliths. Rounded periclase crystals, generally $0.07 \mathrm{~mm}$ diameter, are commonly altered to brucite. Alteration of periclase crystals to brucite is complete in the dark bands which 
cut the rock, but is slight elsewhere. Periclase is commonly associated with magnesioferrite grains, and commonly contains minute cubic or octahedral inclusions of magnesioferrite. Magnetite-magnesioferrite occurs rarely as grains up to $5 \mathrm{~mm}$ (associated with pyrhotite and alabandite), and ubiquitously through the rock as $0.05 \mathrm{~mm}$ diameter equant anhedra or subhedra. Pyrrhotite, apatite, and calcite occur as inclusions in magnesioferrite, and no exsolution textures are present. Rare magnetite grains contain cores of brown-green spinel, and have probably been disaggregated from aluminous inclusions.

Apatite occurs as stubby, euhedral prisms $(0.2 \mathrm{~mm} \times 0.07 \mathrm{~mm})$ throughout the rock, which are larger (up to $0.7 \mathrm{~mm} \times 0.4 \mathrm{~mm}$ ) in elongate apatite-rich segregations. Olivine $\left(2 \mathrm{~V}=90^{\circ}, \delta=0.035\right)$ forms rounded, subhedral grains $(0.04 \mathrm{~mm}$ diameter $)$ scattered rarely throughout the rock. They are more common near the silicate-rich inclusions than in the remainder of the rock, but show no evidence of reaction or dissolution. Some contain clouds of 6 micron diameter polyphase inclusions, which may be crystallized melt inclusions.

Pyrrhotite and alabandite, the only primary sulfide minerals, most commonly occur together as adjacent, rounded grains $(0.5 \mathrm{~mm}$ diameter) touching manganoan magnetite. Both sulfide minerals also occur rarely as isolated euhedra. The larger alabandites contains euhedral inclusions of pyrrhotite oriented along crystallographic directions, probably in an exsolution texture. Smaller alabandite grains contain scattered, minute blebs of pyrhotite. Alabandite is commonly replaced by a fine-grained, carbonate-rich intergrowth. Pyrrhotite grains contain rare elongate inclusions (exsolutions?) of alabandite.

Xenoliths rich in silica and alumina are texturally similar to the host carbonatite, and contain common olivine and magnetitemagnesioferrite. Spinel forms small $(0.07 \mathrm{~mm})$ anhedral grains in the matrix carbonate and inclusions in magnetite-magnesioferrite. Calcite, dolomite, and apatite are present, but pyrrhotite is rare and periclase and alabandite are absent.

Opaque oxide inclusions, up to $4 \mathrm{~cm}$ diameter, are rare. Magnetite-magnesioferrite forms up to $80 \%$ of the inclusions, with interstitial calcite, dolomite, and apatite. Pyrrhotite euhedra are present, but no olivine or alabandite is present.

Late and secondary minerals include rare hematite and pyrite replacing magnetite and pyrrhotite along fractures, brucite after periclase, and barite along late fractures.

\section{Appendix 2: Electron microprobe procedures}

All mineral analyses were performed on the modified ARL EMX microprobe available through the Electron Microbeam Laboratory, Department of Materials and Metallurgical Engineering, The University of Michigan. All analyses were by crystal spectrometer, using $\mathrm{LiF}, \mathrm{ADP}$, and TAP crystals. Accelerating voltage was $15 \mathrm{kV}$, and beam current was digitized to control count time. All analyses were done with a focused beam except for analyses of apatite and carbonates, which were done with a 6 micron defocused beam to minimize volatilization and specimen damage. Standards and sample currents utilized are as follows:

apatite $\quad 0.010$ micro-amp.

apatite $(\mathrm{Ca}, \mathrm{P}, \mathrm{F})$, strontianite $(\mathrm{Sr})$, olivenite $(\mathrm{As}), \mathrm{Ba}-\mathrm{Cl}$ apatite $(\mathrm{Cl})$

carbonates 0.005 micro-amp. calcite $(\mathrm{Ca})$, dolomite $(\mathrm{Ca}, \mathrm{Mg})$, siderite $(\mathrm{Fe})$, rhodonite $(\mathrm{Mn})$, strontianite $(\mathrm{Sr}), \mathrm{BaSi}_{2} \mathrm{O}_{5}(\mathrm{Ba})$

forsterite $\quad 0.010$ micro-amp. olivine $(\mathrm{Mg}, \mathrm{Si}, \mathrm{Fe})$, rhodonite $(\mathrm{Mn})$, pyroxene $(\mathrm{Ca})$

oxides $\quad 0.010$ micro-amp. iron metal $(\mathrm{Fe}), \mathrm{MnO}_{2}(\mathrm{Mn})$, $\mathrm{MgTiO}_{3}(\mathrm{Mg}, \mathrm{Ti})$, chromite $(\mathrm{Cr}, \mathrm{Ti}, \mathrm{Al})$

periclase $\quad 0.007$ micro-amp. $\mathrm{MgO}(\mathrm{Mg})$, olivine $(\mathrm{Fe})$, rhodonite $(\mathrm{Mn})$ sulfides $\quad 0.015$ micro-amp. $\quad$ troilite $(\mathrm{Fe}), \mathrm{MnS}(\mathrm{Mn}, \mathrm{S})$, sphalerite $(\mathrm{Zn})$, olivine $(\mathrm{Mg})$.

Data were reduced with the computer program EMPADR VII (Rucklidge and Gasparrini 1969), which uses a ZAF correction procedure. Further details of analyses are available on request.

Acknowledgements. This paper has benefitted from helpful suggestions by Drs. PL Cloke, J Gittins, WC Kelly, TY Tien, JW Valley, and RF Wendlandt. The authors are grateful to the Phoenix Laboratory, The University of Michigan, for providing neutron activation analyses and to the Electron Microbeam Laboratory (Drs. WC Bigelow and LF Allard, directors), The University of Michigan, for use and maintainence of the electron microprobe. This work was supported in part by grant EAR79-23664 from the National Science Foundation.

\section{References}

Anovitz LM, Essene EJ (1982) Phase relations in the system $\mathrm{CaCO}_{3}-\mathrm{MgCO}_{3}-\mathrm{FeCO}_{3}$. EOS (Trans Am Geophys Un) $63: 464$

Aspden JA (1981) The composition of solid inclusions and the occurrence of shoritite in apatites from the Tororo carbonatite complex of eastern Uganda. Mineral Mag 44:201-204

Barton, PB Jr (1970) Sulfide petrology. Mineral Soc Am Spec Pap $3: 187-198$

Boettcher AL, Robertson JK, Wyllie PJ (1980) Studies in synthetic carbonatite systems: solidus relationships for $\mathrm{CaO}-\mathrm{MgO}-$ $\mathrm{CO}_{2}-\mathrm{H}_{2} \mathrm{O}$ to $40 \mathrm{kbar}$ and $\mathrm{CaO}-\mathrm{MgO}-\mathrm{SiO}_{2}-\mathrm{H}_{2} \mathrm{O}$ to 10 kbar. J Geophys Res 85B:6937-6943

Boettcher AL, Wyllie PJ (1969) The system $\mathrm{CaO}-\mathrm{SiO}_{2}-\mathrm{CO}_{2}-$ $\mathrm{H}_{2} \mathrm{O}$ - III Second critical end-point on the melting curve. Geochim Cosmochim Acta 33:611-632

Bohlen SR, Essene EJ (1977) Feldspar and oxide thermometry of granulites in the Adirondack highlands. Contrib Mineral Petrol 62:153-169

Burnham CW, Holloway JR, Davis NF (1969) Thermodynamic properties of water to $1,000^{\circ} \mathrm{C}$ and 10,000 bars. Geol Soc Am Spec Pap 132, $96 \mathrm{p}$

Clark SP Jr ed (1966) Handbook of Physical Constants. Geol Soc Am Mem 97, $587 \mathrm{p}$

Eby GN (1975) Abundance and distribution of the rare earth elements and yttrium in the rocks and minerals of the Oka carbonatite complex, Quebec. Geochim Cosmochim Acta 39:597-620

Engi M (1980) The solid solution behavior of olivine in the temperature range from $500 \mathrm{~K}$ to $1,500 \mathrm{~K}$. Geol Soc Am Abstr. Prog 12:421

Essene EJ (1982) Geologic thermometry and barometry. Chap 5, 153-206 In Ferry J ed, Reviews in Mineralogy 10: Characterization of Metamorphism through Mineral Equilibria

Essene EJ, Wall VJ, Westrum EF Jr (1980) Thermodynamics and phase equilibria for fayalite. Geol Soc Am Abstr Prog 12:422

Eugster HP, Skippen GB (1967) Igneous and metamorphic reactions involving gas equilibrium. In Abelson, ed. Researches in Geochemistry, vol II, John Wiley \& Sons, pp 492-520

Fanelli MF, Cava N, Wyllie PJ (1981) Co-precipitation of calcite and dolomite without portlandite in $\mathrm{CaO}-\mathrm{MgO}-\mathrm{CO}_{2}-\mathrm{H}_{2} \mathrm{O}$ at $2 \mathrm{kbar}$ illuminates carbonatite petrogenesis. EOS (Trans Am Geophys Un) 62:413

Fukuoka M (1981) Mineralogical and genetical study on alabandite from the manganese deposits of Japan. Mem Fac Sci Kyushu Univ, Ser D Geol 24:207-251

Gittins J (1979) Problems inherent in the application of calcitedolomite thermometry to carbonatites. Contrib Mineral Petrol $69: 1-4$

Gittins J, McKie D (1980) Alkalic carbonatite magmas: Oldoinyo Lengai and its wider applicability. Lithos 13:213-215

Gold DP (1963) The relationships between the limestones and the alkaline rocks of Oka and St. Hilaire, Quebec. PhD Diss McGill Univ, Montreal 
Gold DP (1967) Alkaline ultrabsic rocks in the Montral area, Quebec. In Wyllie PJ ed, Ultramafic and Related Rocks. J Wiley and Sons, New York, p 288-302

Gold DP (1972) The Monteregian hills: ultra-alkaline rocks and the Oka complex. Intl Geol Cong 24th, Montral, Guidebook B-11

Gold DP, Vallée M (1969) Excursion geologique dans la region d'Oka. Ministere des richesses naturelles Quebec, pub S-101, $37 \mathrm{p}$

Gold DP, Vallée M, Charette J-P (1967) Economic geology and geophysics of the Oka alakaline complex, Quebec. Can Inst Min Metall Bull 60:1131-1144

Goldsmith JR, Newton BC (1969) P-T-X relations in the system $\mathrm{CaCO}_{3}-\mathrm{MgCO}_{3}$ at high temperature and pressure. Am J Sci 267A: $160-190$

Graf DL, Goldsmith JR (1955) Dolomite-magnesian calcite relations at elevated temperatures and $\mathrm{CO}_{2}$ pressures. Geochim Cosmochim Acta 10:109-118

Graf DL, Goldsmith JR (1958) The solubility of $\mathrm{MgCO}_{3}$ in $\mathrm{CaCO}_{3}$ : a revision. Geochim Cosmochim Acta 13:218-219

Harker RI, Tuttle OF (1955) Studies in the system $\mathrm{CaO}-\mathrm{MgO}-$ $\mathrm{CO}_{2}$. Part I The thermal dissociation of calcite, dolomite, and magnesite. Am J Sci 253:209-224

Harrington BJ (1907) Isomorphism as illustrated by certain varieties of magnetite. Mineral Mag 14:373-377

Heinrich EW (1966) The Geology of Carbonatites. J Wiley \& Sons, NY $555 \mathrm{p}$

Hewitt DA (1978) A redetermination of the fayalite-magnetitequartz equilibrium between 650 and $850^{\circ} \mathrm{C}$. Am J Sci 278:715-724

Katsura T, Kimura S (1965) Equilibria in the system FeO$\mathrm{Fe}_{2} \mathrm{O}_{3}-\mathrm{MgO}$ at $1,160^{\circ} \mathrm{C}$, Bull Chem Soc Japan 38:1664-1670

Kerrick DM, Jacobs GK (1981) A modified Redlich-Kwong equation for $\mathrm{H}_{2} \mathrm{O}, \mathrm{CO}_{2}$, and $\mathrm{H}_{2} \mathrm{O}-\mathrm{CO}_{2}$ mixtures at elevated pressures and temperatures. Am J Sci 281:735-767

Lindsley, DH (1976) Experimental studies of oxide minerals. In Rumble D III ed, Oxide Minerals, Short Course Notes 3, Mineral Soc Am, L61-L87

Loubet M, Bernat M, Javoy M, Allegre CJ (1972) Rare earth contents in carbonatites. Earth Planet Sci Lett 14:226-232

Mann GS, van Vlack LH (1976) FeS-MnS phase relationships in the presence of excess iron. Metall Trans 7B:469-475

Mariano AN, Roeder PL (1983) Kerimasi : A neglected carbonatite volcano. J Geol 91:449-455

McMahon BM, Haggerty SE (1979) The Oka carbonatite complex: magnetite compositions and the related role of titanium in pyrochlore. In Boyd FR, Meyers HOA, eds Kimberlites, Diatremes, and Diamonds: Their Geology, Petrology, and Geochemistry. Am Geophys Union, Wash DC, pp 382-392

Myers J, Eugster HP (1983) The system Fe-Si-O: Oxygen buffer calibrations to 1,500K. Contrib Mineral Petrol 82:75-90

Nesbitt BE, Kelly WC (1977) Magmatic and hydrothermal inclusions in carbonatite of the Magnet Cove complex, Arkansas. Contrib Mineral Petrol 63:271-294

Rankin AH (1975) Fluid inclusion studies in apatite from carbonatites of the Wasaki area of western Kenya. Lithos 8:123-136

Rankin AH (1977) Fluid-inclusion evidence for the formation conditions of apatite form the Tororo carbonatite complex of eastern Uganda. Mineral Mag 41:155-164

Rice JM (1977) Contact metamorphism of impure dolomitic limestone in the Boulder aureole, Montana. Contrib Mineral Petrol $59: 237-259$

Robie RA, Hemingway BS, Fisher JR (1979) Thermodynamic properties of minerals and related substances at $298.15 \mathrm{~K}$ and
1 bar $\left(10^{5}\right.$ pascals $)$ pressure and at higher temperatures. US Geol Surv Bull 1452 revised, $456 \mathrm{p}$

Robie RA, Finch CB, Hemingway BS (1982) Heat capacity and entropy of fayalite $\left(\mathrm{Fe}_{2} \mathrm{SiO}_{4}\right)$ between 5.1 and $383 \mathrm{~K}$ : comparison of calorimetric and equilibrium values for the QFM buffer reaction. Am Mineral 67:463-469

Rucklidge JC, Gasparrini EL (1969) Specifications of a complete program for processing electron microprobe data: EMPADR VII. Dept of Geology, Toronto University, unpublished circular

Ryzhenko BN, Volkov VP (1971) Fugacity coefficients of some gasses in a broad range of temperatures and pressures. Geochem Int1 8:468-481

Saxena SK (1973) Thermodynamics of Rock-Forming Crystalline Solutions. Springer-Verlag, NY, $188 \mathrm{p}$

Shishkov VI, Lykasov AA, Il'ina AF (1980) Activity of the components of iron-magnesium spinel. Russ Jour Phys Chem $54: 440-441$

Shmulovich KI, Mazur VA, Kalinichev AG, Khodorevskaya LI (1982) P-V-T and component activity-concentration relations for systems of the $\mathrm{H}_{2} \mathrm{O}$-non-polar gas type. Geochem Intl $1980: 18-30$

Skinner BJ, Luce FD (1971) Solid solutions of the type (Ca, Mg, $\mathrm{Mn}, \mathrm{Fe}) \mathrm{S}$ and their use as geothermometers for enstatite chondrites. Am Mineral 56:1269-1296

Slaughter J, Wall VJ, Kerrick DM (1976) APL computer program for thermodynamic calculations of quilibria in $\mathrm{P}-\mathrm{T}-\mathrm{X}_{\mathrm{CO}_{2}}$ space. Contrib Mineral Petrol 54:157-171

Speidel DH (1967) Phase equilibria in the system $\mathrm{MgO}-\mathrm{FeO}-$ $\mathrm{Fe}_{2} \mathrm{O}_{3}$ : the $1,300^{\circ} \mathrm{C}$ isothermal section and extrapolations to other temperatures. J Am Ceram Soc 50:243-248

Stull DR, Prophet H eds (1971) JANAF Thermochemical Tables, Second Edition. National Standard Reference Data Ser 37, National Bureau Standards, 1,141 p

Toulmin P III, Barton PB Jr (1964) A thermodynamic study of pyrite and pyrrhotite. Geochim Cosmochim Acta 28:641-671

Treiman AH (1982) The Oka carbonatite complex Quebec: aspects of carbonatite petrogenesis. PhD Diss Univ Michigan, Ann Arbor

Treiman AH, Essene EJ (1983) High-termperature phase equilibria in $\mathrm{CaO}-\mathrm{SiO}_{2}-\mathrm{CO}_{2}$. Am J Sci 283A:97-120

Van de Pijpekamp B, Burke EAS, Maaskant P (1969) Magnesioferrite, a new mineral for Långban, Sweden. Arkiv for mineralogi och geology $5: 1-10$

Vuklovich MP, Altunin VV (1965) Teplofizicheskiye Svoystva Dvuokiski Ugleroda (Thermophysical Properties of Carbon Dioxide) Atomizdat, Moscow

Westrich HR, Navrotsky A (1981) Some thermodynamic properties of fluorapatite, fluorpargasite, and fluorphlogopite. Am J Sci $281: 1091-1103$

Wones DR, Gilbert MC (1969) The fayalite-magnetite-quartz assemblage between $600^{\circ}$ and $800^{\circ} \mathrm{C}$. Am J Sci 267A:480-488

Wyllie PJ, Biggar GM (1966) Fractional crystallization in the "carbonatite systems" $\mathrm{CaO}-\mathrm{MgO}-\mathrm{CO}_{2}-\mathrm{H}_{2} \mathrm{O}$ and $\mathrm{CaO}-$ $\mathrm{CaF}_{2}-\mathrm{P}_{2} \mathrm{O}_{5}-\mathrm{CO}_{2}-\mathrm{H}_{2} \mathrm{O}$. Mineral Soc India, IMA vol, p 6782

Wyllie PJ, Haas JL Jr (1965) The system $\mathrm{CaO}-\mathrm{SiO}_{2}-\mathrm{CO}_{2}-\mathrm{H}_{2} \mathrm{O}$ : 1. Melting relationships with excess vapor at 1 kilobar pressure. Geochim Cosmochim Acta 29;871-889

Wyllie PJ, Tuttle OF (1960) The system $\mathrm{CaO}-\mathrm{CO}_{2}-\mathrm{H}_{2} \mathrm{O}$ and the origin of carbonatites. J Petrol 1:1-46

Received March 4, 1983; Accepted October 10, 1983 